\title{
King Leads MRS Executive Committee in 2002
}

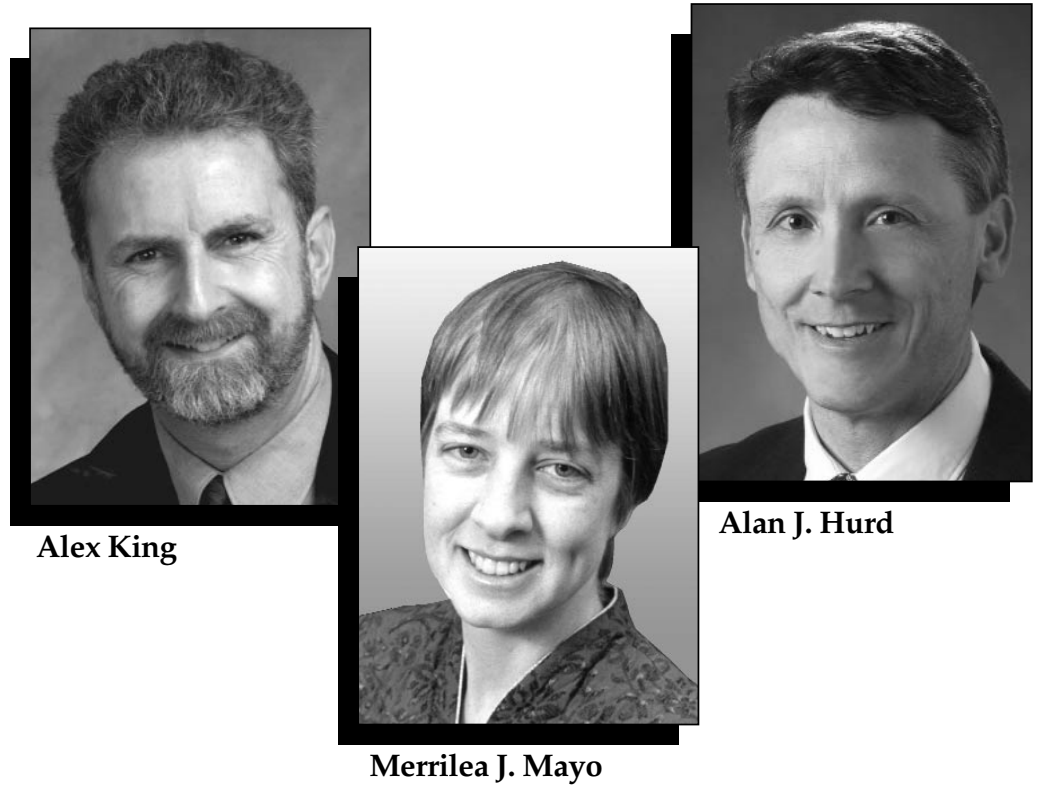

Alex King (Purdue University) automatically assumes the presidency of the Materials Research Society for 2002, after serving as Vice President (PresidentElect) in 2001. He succeeds Martin L. Green from Agere Systems, who now serves MRS as Immediate Past President.

Merrilea J. Mayo (GUIRR, National Research Council) has been elected Vice President/President-Elect, leaving a position open for Treasurer to be filled by appointment. Alan J. Hurd (Los Alamos National Laboratory) has been elected Secretary. The Council elected Linda L. Horton (Oak Ridge National Laboratory) and Paul S. Peercy (University of Wisconsin-Madison) to serve one-year terms as council liaisons to the Executive Committee.

The newly elected MRS Councillors are Bruce M. Clemens, Stanford University; Tomás Díaz de la Rubia, Lawrence Livermore National Laboratory; Jerrold A. Floro, Sandia National Laboratories; Mihal Gross, IPsci Dimensions; Akihisa Inoue, Tohoku University; and Cynthia A. Volkert, Max Plank Institute for Metals Research. They will serve three-year terms beginning January 1, 2002, and join the following current members of Council: Eduard Arzt, Max Planck Institute; Orlando Auciello, Argonne National Laboratory; Peter F. Green, University of Texas-Austin; Linda L. Horton, Oak Ridge National Laboratory; Howard E. Katz, Lucent Technologies; Anne M. Mayes, Massachusetts Institute of Technology; Paul S. Peercy, University of Wisconsin-Madison; Julia R.
Weertman, Northwestern University; and R. Stanley Williams, Hewlett-Packard Laboratories. The Executive Committee appointed former MRS Secretary Chuang Chuang Tsai (Quanta Display, Inc.) as a member on Council, and expects to appoint one of the Councillors as Treasurer.

\section{Alex King \\ President}

Alex King is a professor and head of the School of Materials Engineering at Purdue University. He was previously a professor in the Department of Materials Science and Engineering at the State University of New York-Stony Brook, where he also served as vice provost for graduate studies. His research program focuses on interfacial structures and behavior, with extended interests in other areas including thin films, semiconductors, polymers, and materials processing. King received his BMet degree from the University of Sheffield and his doctoral degree, in 1979, from Oxford University. Following a brief period as a research fellow at Oxford, King joined the Massachusetts Institute of Technology as a postdoctoral associate. He joined the SUNY faculty in 1981.

At MRS, King just ended his service as Vice President/President-Elect to step into the position of President. He served on the Program Committee and its Meetings Quality Subcommittee. He was a symposium organizer at the 1993 MRS Fall Meeting and co-chair of the 1997 MRS Spring Meeting, where he implemented the Meeting Chairs' Poster Prize. He served on the MRS Council from 1998 to 2000 , including two consecutive tenures as Council liaison to the Executive Committee. He has been a regular contributor to POSTERMINARIES in MRS Bulletin.

\section{Merrilea J. Mayo}

Vice President

(President-Elect)

Merrilea J. Mayo is the director of the Government-University-Industry Research Roundtable (GUIRR), sponsored by the National Academies and guided by the National Research Council (NRC). She comes to the Academies from The Pennsylvania State University, where she was an associate professor in the Materials Science and Engineering Department, focusing on nanocrystalline ceramics. She received her $\mathrm{PhD}$ degree in materials science and engineering from Stanford University in 1988.

Mayo received fellowships from the Japan Society for the Promotion of Science (1993) and the Exxon Foundation (19821984), as well as an NSF Presidential Young Investigator Award (1991-1996). She served on the NRC's Advisory Panel 
on the National Institute of Standards and Technology (NIST) and on the NRC's Advisory Committee on Army After Next (AAN) Logistics. She helped organize the Alliance for Science and Technology Research in America (ASTRA). Mayo has over 50 authored and co-authored publications.

Within MRS, Mayo has served on the External Affairs and Public Affairs Committees since 1994 and previously served on the Graduate Student Award Subcommittee, the Program Planning Committee, and the Long-Range Planning Committee; she has also been a Councillor, a meeting chair, and symposium organizer. She was part of the MRS Headquarters Building Task Force and is involved in developing the Societyís materials-related interactive displays then known as Materials MicroWorld, supported by a grant from the National Science Foundation. She was selected as the Materials Research Society/Optical Society of America Congressional Science and Engineering Fellow for 1998-1999 and served her fellowship working on research and development issues in the office of Senator Joseph Lieberman. Mayo left her position of MRS Treasurer upon her election as Vice President/ President-Elect.

\section{Alan J. Hurd}

Secretary

Alan J. Hurd is the director of the Manuel Lujan Jr. Neutron Scattering Center of LANSCE at Los Alamos National Laboratory, and is an adjunct professor of physics at the University of New Mexico. He was previously a research manager at Sandia National Laboratories in Albuquerque. His research interests center around complex fluids. He received his PhD degree in physics in 1981 from the University of Colorado.

Hurd served on advisory groups for Los Alamos National Laboratory, the National Research Council, the National Renewable Energy Laboratory, and the University of
New Mexico. He has received three research awards from Basic Energy Sciences of the Department of Energy.

Hurd has served MRS as Treasurer, a Councillor, Membership Committee chair, chair of four task forces, and co-chair of the 1994 MRS Spring Meeting. He was the founding chair of the Public Outreach Subcommittee and is the founding chair of the Materials MicroWorld Oversight Committee. For his efforts in securing NSF funding for Materials MicroWorld, Hurd was honored with the 1999 MRS Woody Award.

\section{Martin L. Green \\ Immediate Past President}

Martin L. Green is a member of technical staff in the Silicon Electronics Research Laboratory at Agere Systems in Murray Hill, N.J. For the past five years, he has focused his research on the growth and characterization of ultrathin dielectric films for silicon microelectronics applications. His other research interests have included rapid thermal processing, chemical vapor deposition, semiconductor heterostructures, martensitic phase transformations, plasticity of ordered alloys and ionic crystals, magnetic materials, and powder metallurgy.

After receiving his BS (1970) and MS (1972) degrees in metallurgy from the Polytechnic Institute of Brooklyn, Green received his $\mathrm{PhD}$ degree (1978) in materials science from the Massachusetts Institute of Technology. He is author or co-author of over 100 refereed papers and has edited several books. He also holds 12 patents.

During his involvement with MRS since 1976, Green has co-organized four symposia, served as a meeting chair for the 1993 Spring Meeting, chaired the MRS Bulletin Book Review Board, and served as Councillor (1995-1998), during which time he nurtured the concept of MRS workshops, four of which have been held. As Vice President/ President-Elect in 2000, he was President in 2001, and will serve on the Executive Committee as Immediate Past President in 2002.

\section{Linda L. Horton \\ Councillor}

Linda L. Horton is the program director for the Basic Energy Sciences Metals and Ceramic Sciences Program at Oak Ridge National Laboratory (ORNL). Her research has emphasized applications of electron microscopy to materials science problems and has included investigations of the effects of ion implantation and neutron irradiation on the structure and properties of ferritic alloys and ceramic materials and studies of the growth and characterization of diamond thin films. Horton received her PhD degree in materials science in 1981 from the University of Virginia.

Horton participated in the MRS Grassroots Education activities in 1991-1994 and has served as session chair for several MRS meetings. She was elected to MRS Council last year.

\section{Paul S. Peercy \\ Councillor}

Paul S. Peercy is dean of the College of Engineering and professor of Materials Science and Engineering at the University of Wisconsin-Madison. From 1995 to 1999 , he was president of SEMI/SEMATECH, and before that he served as director of microelectronics and photonics at Sandia National Laboratories. He received his PhD degree from the University of Wisconsin-Madison. His research has spanned several areas of solid-state and materials physics and engineering. $\mathrm{He}$ is the author or co-author of over 180 papers and holds two patents.

Peercy has served MRS in several capacities: chair of the Program Committee, chair of the Washington Materials Forum, symposium organizer, meeting chair, Vice President, and Councillor, and he received the MRS Woody Award for service to the Society. This is his second term serving as Council liaison to the Executive Committee.

\section{MRS special delivery}

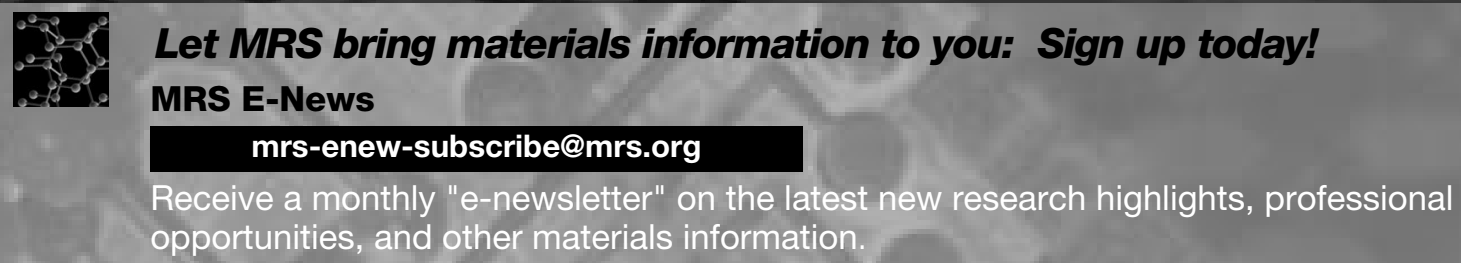

www.mrs.org...the Materials Gateway 


\section{Werwa Accepts MRS/OSA Congressional Fellowship Position with Rep. Honda}

Eric Werwa, the Materials Research Society/Optical Society of America Congressional Science and Engineering Fellow for 2001-2002, ${ }^{*}$ has accepted a position with U.S. Representative Michael M. Honda, D-Calif. As a new member of the House from Silicon Valley, Rep. Honda serves on the research subcommittee within the House Science Committee. He has advocated for the high-tech community in favor of legislation to augment the research and development tax credit and to eliminate taxes on graduate-school tuition paid by employers. He is forming a bipartisan Task Force on Mobile Commerce to better understand and support innovative companies in the wireless industry.

Werwa expects to work closely with the semiconductor industry, which makes up a large portion of Rep. Honda's constituency. Werwa will also be working in the areas of biotechnology, energy

*See MRS Bulletin 26 (May 2001) p. 409.

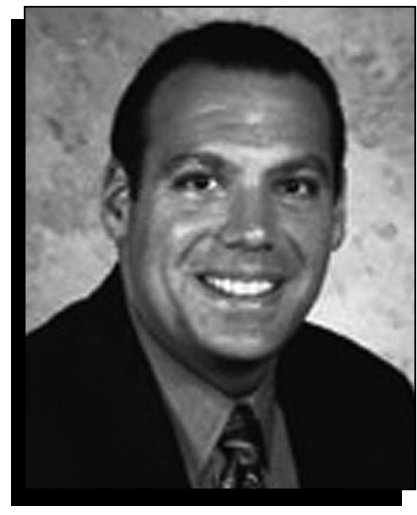

Eric Werwa

issues (including renewable-energy sources), environmental issues, and science education.

"As a former science teacher, Representative Honda appreciates the importance of science and technology in the lives of all Americans and the importance of educating the public about science and technology. This made his office seem like an ideal place for me to work during my fellowship year, one where I should have many opportunities to advance science in the Congress," said Werwa. "We are currently in the process of developing legislation to improve science education and increase funding for scientific research to be introduced in 2002. I invite members of the science community to give me their input into these and other subjects at Eric.Werwa@mail.house.gov."

Susan Ginsberg, the MRS/OSA Congressional Fellow for 2000-2001, worked in the office of Rep. Howard L. Berman, D-Calif. Arun Seraphin (1999- 2000), Merrilea Mayo (1998-1999), and Kelly Kirkpatrick (19951996) worked in the office of Sen. Joseph Lieberman, D-Conn. Michal Freedhoff (1996-1997) and Brian Holloway (19971998) served their fellowships with Rep. Edward J. Markey, D-Mass., and Sen. John D. Rockefeller, D-W.Va., respectively. $\mathrm{M} \mid \mathrm{R}] \mathrm{S}$

\section{JMR Launches Manuscript Central}

In December 2001, the Journal of Materials Research (JMR) launched Manuscript Central, a Web-based manuscript submission and tracking system. Manuscript Central is operated by ScholarOne, a Virginia-based software company specializing in applications for scholarly publishing. It enables Web-based, direct access for authors, reviewers, editors, and editorial office staff.

Manuscript Central's entirely digital workflow promises to shorten the journal's review process, as manuscripts and reviews will be submitted and transmitted electronically between authors, the JMR office, and editors and reviewers worldwide. This is done by giving authors the tools to submit their manuscripts as PDF files, which are then accessible to reviewers and editors through Web links. In addition to the elimination of mailing costs and a more streamlined review process, one of the greatest advantages for authors who submit their manuscripts electronically is the ability to connect to the system at any time to check their manuscript's status and update their own contact information. JMR Principal Editors will now have the tools to search an extensive database of reviewers when making assignments, using expertise keywords to aid in their selections. Manuscript Central's security mechanism allows only the editor and reviewers assigned to a particular manuscript to view that manuscript. Reviewers, whose identities are kept confidential, only have access to the manuscript until their review is submitted.

In early 2000, the introduction of Global Editor, a system maintained by RCP Consultants in the United Kingdom, marked the beginning of $J M R^{\prime} s$ transition to electronic submission and tracking. Manuscript Central will replace Global Editor, which was sold and subsequently shut down at the end of 2001.
$J M R$ is published 12 times a year by the Materials Research Society (MRS) and is devoted to reports of original research and, on occasion, review articles. Its scope encompasses all aspects of materials research, including the preparation, processing, characterization, and theoretical description of materials with new or unusual structures and properties. JMR offers the general public free online access to all abstracts of articles published since the journal's inception at www.mrs. org/publications/jmr/jmra. This site also provides JMR subscribers with the benefit of online access to the complete text of volumes published from 1996 through the current issue.

MRS encourages authors to submit their manuscripts electronically by visiting http://www.mrs.org/publications/jmr, where they can link to detailed submission information and instructions.

\section{MRS special delivery}

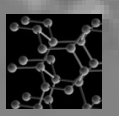

Let MRS bring publications information to you: Sign up today!

Publications Alert

mrs-pubs-alert-subscribe@mrs.org

Review tables of contents in advance for the MRS Bulletin and Journal of Materials Research

www.mrs.org...the Materials Gateway 